\title{
AS PENAS DO ART. 28 DA LEI DE DROGAS E SUAS IMPLICAÇÕES NA ATUAÇÃO E MODOS DE PENSAR DOS JUÍZES E PROMOTORES FEIRENSES // Alana dos Santos Teles ${ }^{1}$
}

\section{Palavras-chave}

lei de drogas / usuários / penas alternativas

HIIIIIIIIIIIIIIIIIIIIIIIIIIIIIIIIII

\section{Sumário}

1 Apresentação do tema e metodologia adotada

2 A nova lei de drogas e a (possível) quebra de paradigma

3 As decisões de juízes e promotores: aspectos quantitativos

3.1 A constituição da amostra

3.2 As concepções através dos processos: a análise dos processos do crime do art. 28 da Lei de Drogas e a atuação dos juízes e promotores feirenses

4 As concepções através das entrevistas: os modos de pensar dos juizes e promotores feirenses em matéria do crime de uso de drogas

4.1 A construção das categorias

4.2 Análise dos discursos à luz das categorias

4.3 Análise geral das categorias

5 Considerações finais

6 Referências

\section{Resumo}

O presente artigo é resultado de uma pesquisa de iniciação científica ${ }^{2}$ cujo objetivo foi estudar como os atores jurídicos envolvidos no enfrentamento do crime de uso de drogas na Comarca de Feira de Santana lidam com a previsão da exclusão da prisão e a imposição de penas alternativas para o crime do art. 28 da Nova Lei de Drogas (Lei 11.343/06). Para tanto, este artigo tece uma análise sobre a possível mudança de paradigma do pensamento penal dominante a partir da edição da Lei $n^{\circ} 11.343 / 06$. Para isso, expomos como foram estudados e analisados os processos relativos ao art. 28 da lei, entre os anos de 2013 a 2015. Apresentamos também como foram realizadas as entrevistas semiestruturadas com os atores jurídicos envolvidos e as informações que pudemos extrair delas, a partir do método da Teoria Enraizada. Por fim, trazemos a análise dos resultados evidenciando como lidam os atores com os processos.
1 Graduanda pela UEFS, integrante do Grupo de Pesquisa em Criminologia UEFS/UNEB, pesquisadora de Iniciação Científica pela FGV/SP.

$2 \mathrm{~A}$ pesquisa de iniciação científica foi desenvolvida no período de agosto de 2015 a julho de 2016 referentes às atividades do Programa de Iniciação Científica da Escola de Direito de São Paulo da Fundação Getúlio Vargas (FGV DIREITO SP) 2015/2016. 
FEATHERS OF ART. 28 THE LAW OF DRUGS AND THEIR

IMPLICATIONS IN PRACTICE AND JUDGES AND PROSECUTORS OF

THINKING MODES FEIRENSES // Alana dos Santos Teles

\section{Keywords}

drug law / users / alternative sentences

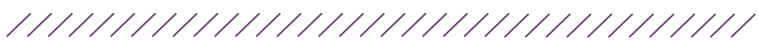

\begin{abstract}
This article is the result of a scientific initiation research whose objective was to study how the legal actors involved in coping with the crime of drug use in the Feira de Santana County deal with the prediction of exclusion from prison and the imposition of alternative sentences for crime of art. 28 of the New Drug Law. In order to do so, this article analyzes the possible paradigm shift of the dominant criminal thinking from the edition of Law $n^{\circ} 11.343 / 06$. For this, we show how the processes related to art. 28 of the law, between the years of 2013 to 2015 . We also present how the semi-structured interviews with the legal actors involved and the information that we extracted from them were carried out, using the Rooted Theory method. Finally, we bring the analysis of the results seeking to answer if there was criminal innovation from the device of the drug law.
\end{abstract}




\section{Apresentação do tema e metodologia adotada}

Diante da clássica estrutura legislativa penal brasileira, a Lei de Drogas de 2006 trouxe uma novidade penal interessante: a exclusão da pena de prisão e a imposição de sanções não encarceradoras para os usuários (PIRES, 2011, p. 299). A notória mudança do sistema político nesse tipo de crime trouxe importantes reflexos e reflexões para o mundo jurídico, passíveis de legitimar ou não a alteração do sistema de pensamento proposta pelo legislador de 2006 . Assim, este artigo apresenta um estudo da atuação e dos modos de pensar dos atores jurídicos em relação às penas estabelecidas para os usuários de drogas, tornando-se relevante para aferir, no locus feirense, se a mudança legislativa proposta em 2006 se sustenta no pensamento penal moderno.

Para tanto, o trabalho buscou conhecer as concepções dos atores do juizado especial criminal, envolvidos no enfrentamento ao crime de porte de drogas para consumo pessoal, na comarca de Feira de Santana, BA. Tal estudo partiu da análise da maneira como esses membros aplicam e pensam as penas do art. 28 da Lei $n^{\circ} 11.343 / 2006$ na cidade, contribuindo assim para os debates sobre as penas alternativas e a construção de um novo pensamento penal.

Para nortear a pesquisa foi formulada a seguinte pergunta inicial: "Como os juízes e promotores de Feira de Santana lidam com as penas do art. 28 da Lei de Drogas?". Das respostas a ela pode-se compreender uma parte da mecânica e operacionalização das normas de comportamento e de sanção do judiciário no âmbito dos juizados e, consequentemente, inferir algumas hipóteses sobre as ideias por trás das decisões dos atores jurídicos envolvidos a respeito do tema.

Quanto ao método, optamos por uma parte teórica para contextualização do tema, e partimos para um estudo quali-quanti: primeiramente através do levantamento e coleta de dados dos processos relativos ao crime de uso de drogas nos anos de 2013-2015, com a posterior descrição e análise desses resultados, e posteriormente por meio de entrevistas semiestruturadas com os juízes e promotores envolvidos no enfrentamento do crime tipificado no art. 28 da lei de drogas.
No que tange à dimensão quantitativa, inicialmente foram levantadas informações gerais através da primeira visita às secretarias dos juizados, na qual se coletou a quantidade geral dos processos existentes em cada uma das varas dos juizados, partindo-se para a produção de amostras. Após, foram elaboradas variáveis sobre o que seria importante ser observado nos processos, sendo estas organizadas em categorias que englobam: pareceres de transação penal, informações do termo circunstanciado, laudo pericial de constatação da droga, audiências e desfecho do processo. Tais informações foram colocadas numa tabela geral ${ }^{3}$ que norteou a tabulação das informações. Com a formulação dos dados representados em tabelas, quantitativamente, passou-se a descrevê-los de acordo com os pontos mais relevantes para os objetivos da pesquisa.

Os dados preliminarmente alcançados na fase apontada serviram de embasamento para a formulação das perguntas para as entrevistas.

Em continuidade, partimos para a metodologia qualitativa por meio das entrevistas. A escolha desse método como instrumento de investigação empírica se deu pela possibilidade de este instrumento oferecer informações que são trazidas e/ou esclarecidas pelo próprio ator social. É, como nos dizeres de Charles Connel e Robert Kahn (1974, p. 323) os "dados sobre experiências passadas e comportamentos futuros não podem ser obtidos por outros meios". Assim, por meio das entrevistas, há a possibilidade de se obter um dado mais próximo da realidade ou do pensamento do interlocutor.

É importante dizer que no decorrer desse processo de entrevista deve-se ter cuidado com o sentido que o próprio ator social dá a sua ação. Danielle Ruquoy chama atenção ao conceito de "ilusão da transparência" que consiste na crença de que o indivíduo conhece por completo os aspectos relativos à sua

3 A tabela geral pode ser visualizada no anexo 1 do Relatório Final de Atividadesda pesquisadoraapresentadoà Fundação GetúlioVargas. Disponível em: https://www.academia.edu/35361129/H\%C3\%A1_ inova $\%$ C3\%A7\%C3\%A30_na_aplica\%C3\%A7\%C3\%A3o_das_penas_aos_usu\%C3\%A1rios_de_drogas_An\%C3\%A1lise_dos_Termos_de_audi\%C3\%AAncia_e_Concep $\%$ C3\%A7\%C3\%B5es_dos_ Ju\%C3\%ADzes_e_Promotores_de_Feira_de_Santana_Ba 
ação. Nas palavras da autora, "se o objetivo é compreender práticas, importa delimitar o modo como os atores as organizam subjetivamente e as valorizam, mas importa igualmente considerar relações sociais que tenham efeitos independentes da consciência dos atores" (RUQUOY, 2005, p. 88).

Dessa forma, buscamos compreender os modos de pensar desses atores sociais, não apenas a partir das próprias percepções deles, mas também e principalmente, a partir das ideias deles e como estas são representadas mediante as suas atuações no campo empírico.

O tipo de entrevista escolhida foi a semidiretiva ou semiestruturada. Nesse tipo de entrevista o entrevistador possui um objetivo de pesquisa específico, mas não necessariamente interfere nas respostas do interlocutor. Em outras palavras, é permitido e estimulado que o próprio entrevistado estruture o seu pensamento em torno do objeto, cabendo ao investigador zelar pela pertinência das afirmações relativamente ao objetivo da pesquisa, aprofundando os pontos não mencionados pelo entrevistado, se necessário (RUQUOY, 2005). Assim, foi criado um roteiro de perguntas para nortear as entrevistas, sendo utilizado quando necessário.

Para a extração dos dados e a análise das informações obtidas com as entrevistas foi utilizada, com importantes ressalvas, a "Teoria Fundamentada nos Dados" de Glaser \& Straus (1967). Essa formulação teórica foi pensada por seus autores como uma metodologia que permite a elaboração de conhecimento através da observação de dados qualitativos empíricos, e que posteriormente podem se tornar objeto de verificação e de discussão à luz de outras formulações já existentes. Trata-se de um método prevalentemente indutivo, mas, como elucida Riccardo Cappi $(2014$, p. 13) "não se trata aqui de sustentar que a TFD seja indutiva no sentido puro da palavra, o que seria de fato impossível, pois a observação sempre é guiada por uma pré-leitura 'teórica' da realidade por parte do observador-pesquisador".

Assim, neste trabalho, a referida teoria não foi utilizada em seu sentido forte, ou seja, eminentemente indutiva, pois o roteiro de entrevista foi em parte elaborado a partir da observação da fase quantitativa.
No entanto, a proposta da realização das entrevistas não se limitava a verificação das hipóteses preliminarmente construídas, mas também objetivou a descoberta de novas hipóteses e conclusões acerca das concepções dos atores jurídicos. Assim, a TFD se fez bastante viável como método voltado à descoberta de novos dados e formulações de novas hipóteses, que seriam dificilmente obtidas de maneira diversa.

Para realizar a análise a partir da observação, pela TFD, é necessário um processo de codificação sistemática ${ }^{4}$, que parte de três etapas fundamentais: a codificação aberta, a codificação axial e a codificação seletiva.

Dessa forma, foram constituídos e analisados os dados empíricos que emergiram no estudo, para posterior verificação à luz de uma teoria ou construção de nova formulação teórica.

\section{A nova Lei de Drogas e a (possível) quebra de paradigma}

A política legislativa sobre drogas no Brasil, até o ano de 2006, estabelecia como medida central para a repressão do uso, penas eminentemente privativas de liberdade como sanção ao indivíduo que fosse pego portando, para consumo próprio, alguma substância considerada ilícita.

Em 2006, a Lei $n^{\circ} 11.343 / 06$, conhecida como Nova Lei de Drogas, revogou as leis $n^{\circ} 10.409 / 2002$ e $^{\circ}$ $6.368 / 76$. Prescreveu, em contrapartida às anteriores, aos usuários de drogas ou qualquer indivíduo que cometesse alguma das figuras típicas previstas no caput do art. 28 (adquirir, guardar, ter em depósito, transportar e trazer consigo para consumo pessoal drogas consideradas ilícitas) as penas de advertência, prestação de serviços à comunidade e medidas de comparecimento a cursos e programas educativos. Em outras palavras, as penas que o art. 28 estabeleceu "fogem" do caráter aflitivo que até então a legislação sobre drogas estabelecia para os usuários, pois em nenhuma hipótese estes podem ser privados de liberdade. Há, portanto, a total exclusão da prisão e a previsão de penas alternativas, na contramão do pensamento penal dominante da racionalidade penal moderna.

4 Para maiores informações vide CAPPI, 2014, p. 12-15. 
A racionalidade penal moderna ${ }^{5}$ é um sistema de pensamento penal que se desenvolveu no mundo ocidental a partir da metade do séc. XVIII, relativo à justiça criminal, que foi identificado por Álvaro Pires (1998, pp. 3-52; 2004, pp.40-47). Essa teoria possui como um de seus efeitos naturalizar a estrutura normativa eleita pelo sistema penal. Assim, para todo preceito primário (norma de comportamento - definição do crime), deve estar estabelecido um preceito secundário (norma de sanção) devendo este causar necessariamente algum tipo de sofrimento ao indivíduo (pena de morte, prisão, multa), é o que o autor denomina de estrutura telescópica da norma. Tem-se como problemas dessa estrutura, a definição do crime (todo) pela pena (parte), a ilusão de simplicidade quanto ao trabalho do legislador e do juiz (numa simples relação de causa e efeito), e o pensamento de que a combinação crime/pena deveriam estar necessariamente associadas.

Considerando esse sistema de pensamento, com a edição da Lei $n^{\circ}$ 11.343/06, Álvaro Pires e Jean-François Cauchie (2011, p. 299-330) aduzem que houve uma novidade, que eles chamam de inovação "acidental" em matéria de penas. Isto porque a nova lei surge em contramão ao paradigma dominante da racionalidade penal moderna, acostumado com penas que impunham alguma forma de dor. Nas palavras dos autores, "uma 'ação inovadora' (ou um acontecimento inovador) é aquela que modifica uma estrutura, que produz uma reprodução inovadora da estrutura de referência" (Ibidem, p. 305). Pensa-se, portanto, uma nova forma de lidar com o indivíduo considerado infrator.

Tais penas foram/são objeto de grande discussão e divergência na doutrina e jurisprudência. Logo após o sancionamento da lei houve o questionamento sobre a despenalização ou não na conduta de posse de drogas para consumo pessoal. O STF ${ }^{6}$, na época, ratificou

5 Para maiores informações vide PIRES, 2004, p. 40-47.

6 (STF - RE: 430105 RJ, Relator: Min. Sepúlveda Pertence, Data de Julgamento: 13/02/2007, Primeira Turma, Data de Publicação: Dje-004 DIVULG 26-04-2007 PUBLIC 27-04-2007 DJ 27-04-2007 PP00069 EMENT VOL-02273-04 PP-00729 RB V. 19, N. 523, 2007, P. 17-21 RT V. 96 , N. 863,2007 , p. 516-523. O presente Recurso foi interposto pelo Ministério Público do Estado do Rio de Janeiro sob o argumento da extinção da punibilidade do fato baseado no art. o posicionamento de que houve uma verdadeira despenalização da conduta do art. 28, entendida como exclusão, para o tipo das penas privativas de liberdade.

Outros doutrinadores, ainda, questionaram ter havido descriminalização das condutas tipificadas pelo art. 28. Essas medidas foram classificadas por aqueles como condutas sui generis (GOMES, et al, 2006, p. 5) pois não seriam nem crime nem contravenção, baseados no art. $1^{\circ}$ da LICPB que considera crime infração penal que comine pena de reclusão ou detenção.

Essas visões e posicionamentos de diversos autores são fruto do pensamento penal dominante que não considera as penas do artigo 28 como verdadeiras penas, tendo em vista que não prevê o encaminhamento às prisões, manicômios judiciais ou a imposição da multa, questionando, portanto, a validade das penas alternativas ou que não produzam aflição.

Dessa forma, embora esteja previsto em lei, a aplicação do dispositivo depende da aceitação a estabilização no sistema de direito, que é quem vai propor (MP) e aplicar (juiz) a pena, são as chamadas estruturas cognitivas ou de reflexão (PIRES, 2011, p. 309). Pires e Cauchie (2011, p. 307) aduzem que quando a mudança ocorre no plano cognitivo há o questionamento das estruturas dominantes. Doutrina e teorias do direito reveem de forma autocrítica as posições precedentes e encontram respostas aos argumentos que embasam(vam) a reprodução até então vigente. Há, nesses casos, a modificação central do conceito da pena. Em outras palavras, mesmo que seja mais visível, e até mesmo mais durável, a mudança puramente legislativa - como ocorreu na edição da Lei $n^{\circ}$ 11.343/2006 para a figura do usuário - possui uma densidade cognitiva frágil e com pouca capacidade de resistência. Tais autores aduzem ainda que "essa mudança só vai adquirir uma capacidade de resistência se conseguir suscitar uma reflexão teórica interna

107, III do CP - que pugna pela retroatividade da lei que não mais considera o fato como criminoso, ensejando ter havida a descriminalização da conduta do art. 28 da Lei de Drogas. Buscando julgar o caso e sanar divergência doutrinária existente no tocante à abolição criminal da conduta do usuário de drogas, o STF se posicionou afirmando que não havia o que se falar em abolitio criminis da conduta descrita no art. 28 da Lei 11.3143/06, mas sim da despenalização da conduta do usuário. 
ao sistema que, por sua vez, seja também inovadora".

Nesse contexto, a pesquisa a qual remete este artigo se desenvolveu para observar qual a estrutura cognitiva que perpassa as instituições jurídicas feirenses. Buscamos saber quais as concepções dos Juízes e Promotores ligados às Varas dos Sistemas dos Juizados em Feira de Santana sobre o instituto da Nova Lei de Drogas, o que eles entendem sobre a função das medidas e penas alternativas e como eles atuam e aplicam esses dispositivos legais na cidade.

No entanto, a aplicação da lei aqui não deve ser entendida no sentido mecânico, numa leitura de causa e consequência, mas como uma utilização da legislação pelos juízes e promotores, pois o que interessa a este trabalho é identificar a maneira de o "aplicador" produzir decisões que não funcionam como mera aplicação da lei (PIRES, CAUCHIE, 2011, p. 312-313).

\section{As decisões de juízes e promotores: aspectos quantitativos}

Serão tratados aqui o modo como foi constituída a amostra estudada na pesquisa e os resultados quantitativos que puderam ser extraídos dela. Assim, puderam ser elaboradas as primeiras constatações da pesquisa.

\subsection{A constituição da amostra}

Pela Lei $n^{\circ} 11.343 / 06$ o procedimento seguido nos crimes referentes ao "usuário de drogas" é o do Juizado Especial Criminal - Jecrim, de acordo com a Lei 9.099/95 ${ }^{7}$. Para a análise desses processos, foram definidas as seguintes variáveis: lizada em 28 de outubro de 2015, a $1^{\text {a }}$ Vara do Sistema dos Juizados tinha 718 processos digitais, a $2^{\text {a }}$ Vara tinha 531 processos e a $3^{\text {a }}$ Vara tinha 619 processos. Do total de 1.868 processos foi elaborada uma amostra sob os seguintes critérios:

1. Período - de fevereiro a abril dos anos de 2013 a 2015. A escolha dos meses foi feita de acordo com o período de maior incidência de Termos Circunstanciados (TCO) - os quais são lavrados no momento em que o indivíduo é encaminhado para a delegacia e compromete-se a comparecer ao Jecrim - tendo em vista as festas do carnaval, geralmente em fevereiro ou março, e da micareta - festa popular da cidade - em abril. O lapso temporal dos anos foi baseado do ano de unificação das varas (2013) para frente (até 2015), em que seria possível identificar a postura de cada um dos juízes nas decisões.

2. Número de processos - A amostra passou a ter 155 processos na $1^{\text {a }}$ Vara do Sistema dos Juizados, 86 processos na $2^{\mathrm{a}}$ e 78 processo na $3^{\mathrm{a}}$ Vara. Como nem todos os 319 processos tinham tido desfecho, a pesquisadora passou a considerar apenas os processos com algum desfecho, fosse esse:

// a proposta de transação penal, mesmo que ainda não tivesse homologada;

// sentença de homologação;

// sentença de prescrição;

// decisão que remetesse o processo ao juízo comum; ou

// a denúncia.

\begin{tabular}{|l|l|l|l|l|l|}
\hline $\begin{array}{l}\text { TERMO CIRCUNS- } \\
\text { TANCIADO }\end{array}$ & $\begin{array}{l}\text { LAUDO PERICIAL DA } \\
\text { DROGA }\end{array}$ & PARECERES DO MP & $\begin{array}{l}\text { DECISÕES DOS } \\
\text { JUÍZES }\end{array}$ & $\begin{array}{l}\text { TERMOS DE AUDI- } \\
\text { ÉNCIA }\end{array}$ & $\begin{array}{l}\text { DESFECHO DO } \\
\text { PROCESSO }\end{array}$ \\
\hline $\begin{array}{l}\text { características } \\
\text { físicas e sociais dos } \\
\text { autores do fato }\end{array}$ & $\begin{array}{l}\text { natureza e quanti- } \\
\text { dade da droga }\end{array}$ & $\begin{array}{l}\text { para a transação } \\
\text { penal (TP) e ofereci- } \\
\text { mento de denúncia }\end{array}$ & $\begin{array}{l}\text { sentença de ho- } \\
\text { mologação de TP, } \\
\text { de prescrição e de } \\
\text { deslocamento }\end{array}$ & $\begin{array}{l}\text { ocorrência ou não, } \\
\text { oferecimento de TP }\end{array}$ & $\begin{array}{l}\text { modo de finalização } \\
\text { do processo }\end{array}$ \\
\hline
\end{tabular}

Foi necessário estabelecer uma amostra para a coleta de dados dos processos. Em consulta processual rea-

$7 \mathrm{Na}$ Comarca de Feira de Santana houve uma mudança de nomenclatura em razão da unificação e redistribuição dos Juizados, transformando-se em $1^{\text {a }}, 2^{\text {a }}$ e $3^{\text {a }}$ Vara do Sistema dos Juizados conforme a Resolução $n^{\circ} 19$ TJ/BA.
Restaram assim 123 processos para a $1^{\text {a }}$ Vara, 34 processos da $2^{\text {a }}$ Vara e 50 processos da $3^{\text {a }}$ Vara, num total de 207 processos. Todavia, considerando o princípio constitucional da individualização da pena, foram levados em conta as características individuais de cada autor, e não apenas o processo em si. Como alguns processos possuíam mais de um autor a amostra se 
ampliou, passando a ser de 242 (duzentos e quarenta e dois) autores para 207 (duzentos e sete) processos ${ }^{8}$.

A partir dos processos colhidos foi elaborada uma tabela-geral ${ }^{9}$ e definidas algumas variáveis com o escopo de orientar a pesquisa em suas análises posteriores.

\subsection{As concepções através dos processos: a} análise dos processos do crime do art. 28 da Lei de Drogas e a atuação dos juízes e promotores feirenses

A partir da amostra elaborada, tivemos que, de maneira geral, a maioria dos autores é do sexo masculino (96\%), de cor parda (59\%) e possui pelo menos ensino fundamental (60\%). Como mostram as tabelas 1 , 2 e 3 :

Tabela 1. Gênero do Autor do Fato.

\begin{tabular}{|c|c|c|}
\hline \multicolumn{3}{|l|}{ GÊNERO } \\
\hline Masculino & 233 & $96 \%$ \\
\hline Feminino & 9 & $4 \%$ \\
\hline Total & 242 & $100 \%$ \\
\hline
\end{tabular}

Fonte: coleta de dados da pesquisa

Tabela 2. Cor do Autor do Fato.

\begin{tabular}{|l|l|l|}
\hline COR & 9 & $4 \%$ \\
\hline Branca & 142 & $59 \%$ \\
\hline Parda & 48 & $20 \%$ \\
\hline Negra & 43 & $18 \%$ \\
\hline Não consta & 242 & $100 \%$ \\
\hline Total &
\end{tabular}

Fonte: coleta de dados da pesquisa.

Tabela 3. Grau de Escolaridade do Autor do Fato.

\begin{tabular}{|l|l|l|}
\hline GRAU DE ESCOLARIDADE & 14 & $6 \%$ \\
\hline Alfabetizado & 58 & $24 \%$ \\
\hline Fundamental Incompleto & 72 & $30 \%$ \\
\hline Fundamental Completo & 17 & $7 \%$ \\
\hline Médio Incompleto & 33 & $14 \%$ \\
\hline Médio Completo & 3 & $1 \%$ \\
\hline Analfabeto & & \\
\hline
\end{tabular}

8 Para ter acesso aos processos, a autora encaminhou uma carta-formal de apresentação, na qual descrevia o conteúdo e a finalidade da pesquisa, comprometendo-se a manter o sigilo das identidades dos autores do processo. o acesso aos dados se deu através de acesso autorizado ao sistema Projudi. 9 Vide nota 1.

\begin{tabular}{|l|l|l|}
\hline Superior Incompleto & 1 & $0 \%$ \\
\hline Não consta & 44 & $18 \%$ \\
\hline Total & 242 & $100 \%$ \\
\hline
\end{tabular}

Fonte: coleta de dados da pesquisa

No que tange ao tipo de droga, foi feito o referencial a partir das drogas constantes nos laudos periciais, momento em que é comprovada ou não a constatação da droga. Somente em $2 \%(n=5)$ dos casos ( $n=242)$ não havia laudo pericial para a constatação da droga.

\begin{tabular}{|l|l|l|}
\hline \multicolumn{2}{|l|}{ TIPO DE DROGA LAUDO } \\
\hline Inalantes voláteis & 16 & $7 \%$ \\
\hline Cocaína & 84 & $35 \%$ \\
\hline Cannabis Sativa & 92 & $38 \%$ \\
\hline Crack & 22 & $9 \%$ \\
\hline Cannabis Sativa e Cocaína & 6 & $2 \%$ \\
\hline Cannabis Sativa e Crack & 9 & $4 \%$ \\
\hline Crack e cocaína & 6 & $2 \%$ \\
\hline Cannabis e Lança & 1 & $0 \%$ \\
\hline $\begin{array}{l}\text { Inalantes voláteis, crack, } \\
\text { cocaína, maconha }\end{array}$ & 1 & \\
\hline Não consta laudo & 5 & $0 \%$ \\
\hline Total & 242 & $2 \%$ \\
\hline
\end{tabular}

Tabela 4. Tipo de Droga analisada no laudo pericial. Fonte: coleta de dados da pesquisa

Pela Tabela 4 pode-se notar que a droga mais incidente é a Cannabis sativa (38\%), seguida da cocaína (35\%) e do crack (09\%). Os inalantes voláteis (conhecido vulgarmente como lança perfume) e a associação com outros tipos de drogas possuem menor incidência.

Ao se observar o tipo de Transação Penal oferecida pelo Ministério Público, verifica-se que cada promotor possui, em regra, uma proposta pré-definida ou pelo menos privilegiada. Mesmo com a diversidade penal que os incisos do art. 28 da Lei ${ }^{\circ} 11.343 / 06$ podem oferecer - isolados ou cumulativamente (art. 28, I; art. 28, II; art. 28, III; art. 28, I e II; art. 28, I e III; art. 28, II e III; art. 28, I, II e III) -, de maneira geral, os membros do parquet oferecem as seguintes medidas: 
Tabela 5. Tipo de Transação Penal oferecida pelo Ministério Público.

\begin{tabular}{|l|l|l|}
\hline \multicolumn{3}{|l|}{ TIPO DE TP OFERECIDA PELO MP } \\
\hline Art. 28, II ou pena pecuniária & 100 & $41 \%$ \\
\hline Art. 28, III & 101 & $42 \%$ \\
\hline Art. 28, I, II e III & 14 & $6 \%$ \\
\hline Art. 28, II e III & 25 & $10 \%$ \\
\hline Nenhuma & 2 & $1 \%$ \\
\hline Total & 242 & $100 \%$ \\
\hline
\end{tabular}

Fonte: coleta de dados da pesquisa

Pelos dados da tabela 5 percebe-se que a pena mais oferecida é a do art. 28, III (42\%); seguida da pena do art. 28, II ou pena pecuniária (41\%) e da aplicação cumulada dos incisos II e III (10\%). Por uma rápida análise dos dados dessa tabela poder-se-ia inferir que o Ministério Público tem uma maior tendência a oferecer como transação penal a medida de comparecimento a cursos e programas educativos, seguida da prestação de serviços à comunidade. No entanto, por uma análise mais detida dos dados ( vide tabela 6), percebemos que é possível que cada promotor tenha um "perfil" de pena, tendendo a propô-la como transação penal ${ }^{10}$. Assim, por exemplo, as penas do art. 28, III e do art. 28, II ou Pena Pecuniária são as penas dos perfis dos promotores $A$ e $D$, que foram os que mais atuaram nos processos:

Tabela 6. Tipo de Transação Penal oferecida por Promotor.

\begin{tabular}{|c|c|c|}
\hline \multicolumn{3}{|c|}{ TP POR PROMOTOR } \\
\hline \multirow[b]{2}{*}{ A } & 101 autores - art. 28, iii $^{\star}$ & \multirow{2}{*}{103} \\
\hline & 2 autores - art. $28, \mathrm{ii}+$ multa** & \\
\hline B & $\begin{array}{l}14 \text { autores - art. } 28, \mathrm{i} \text {, ii, iii cumulati- } \\
\text { vamente - invariavelmente }\end{array}$ & 14 \\
\hline C & 25 autores - art. $28 \mathrm{ii}^{\star \star \star}$ ou iii ${ }^{\star \star \star \star}$ & 25 \\
\hline $\mathrm{D}$ & 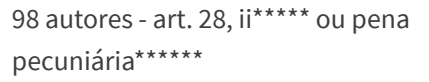 & 98 \\
\hline $\begin{array}{l}\text { não cons- } \\
\text { ta TP }\end{array}$ & & 2 \\
\hline \multicolumn{3}{|c|}{ * palestra no CAPS-AD; } \\
\hline $\begin{array}{l}{ }^{\star \star} \text { prestaçã } \\
\min \end{array}$ & de serviços por 6 meses, 8h/semana & 1 salário \\
\hline
\end{tabular}

10 A Transação Penal é medida alternativa que impede a imposição de pena privativa de liberdade através de sentença condenatória, no entanto constitui sanção penal, sendo uma aplicação imediata da pena, uma antecipação de punição (SALIBA, 2007).

\begin{tabular}{|c|}
\hline${ }^{\star \star \star \star}$ prestação de serviços por 2 meses \\
\hline 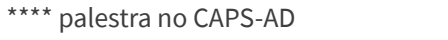 \\
\hline 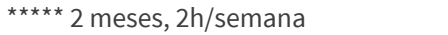 \\
\hline 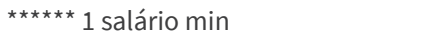 \\
\hline
\end{tabular}

Fonte: coleta de dados da pesquisa

No tocante ao rito seguido pela lei de drogas e ao comparecimento das partes na audiência, a Lei $n^{\circ}$ 11.343/06 determina, para o usuário, o tratamento conferido pela Lei dos Juizados Especiais (Lei $n^{\circ}$ 9.099/99). De acordo com o procedimento desta lei (art. 72), é designada a audiência preliminar na qual, presentes o representante do Ministério Público, o autor do fato e a vítima, é esclarecida pelo juiz a possibilidade de aceitação da proposta de aplicação imediata da pena não privativa de liberdade (transação penal) - neste caso as penas do art. 28, I, II, III -, expedindo-se o termo de audiência.

Apesar da previsão legal acima descrita, foi observado que $43 \%$ das TP foram oferecidas em parecer, e os 57\% restantes não foram oferecidas devido a não ocorrência de audiência (56\%) ou porque a TP não chegou a ser oferecida (1\%) (vide tabela 7). Foi detectado que o Ministério Público não compareceu a nenhuma audiência preliminar a qual o autor também tivesse comparecido ${ }^{11}$, vindo a estar presente em apenas 14 (das 242) audiências, nas quais o autor do fato não compareceu (vide tabela 8). Observamos ainda que as propostas chegam às varas juntamente com os termos circunstanciados, em forma de parecer.

Tabela 7.Momento de Oferecimento da Transação Penal.

\begin{tabular}{|l|l|l|}
\hline TP: OFERECIMENTO EM AUDIÊNCIA \\
\hline TP oferecida em parecer & 103 & $43 \%$ \\
\hline TP oferecida em audiência & 0 & $0 \%$ \\
\hline TP não oferecida & 3 & $1 \%$ \\
\hline Não Houve audiência & 136 & $56 \%$ \\
\hline TOTAL & 242 & $100 \%$ \\
\hline
\end{tabular}

Fonte: coleta de dados da pesquisa

11 Para melhor compreensão, foi considerado pela pesquisadora, como critério para ocorrência ou não de audiência, apenas o comparecimento do autor, tendo em vista que o parecer ministerial da proposta de TP já constaria nos processos. 
Tabela 8. Presença do Ministério Público em Audiência.

\begin{tabular}{|l|l|l|}
\hline \multicolumn{3}{|l|}{ PRESENÇA DO MP NAS AUDIÊNCIAS(por autor) ${ }^{12}$ : } \\
\hline MP e autor compareceram & 0 & $0 \%$ \\
\hline MP e autor não compareceram & 103 & $43 \%$ \\
\hline MP compareceu; autor não compareceu & 14 & $6 \%$ \\
\hline MP não compareceu; autor compareceu & 105 & $43 \%$ \\
\hline S/ marcação de audiência* & 20 & $8 \%$ \\
\hline Total & 2 & $100 \%$ \\
\hline
\end{tabular}

Fonte: coleta de dados da pesquisa

Parece-nos, com isso, que tal procedimento é utilizado para dar maior celeridade ao processo, por não necessitar da presença do parquet. No entanto, se assim o for, fere a intenção da negociação justa ${ }^{13}$ da Transação Penal, tornando-a uma verdadeira imposição, na qual o autor se vê obrigado ou a aceitar a pena "oferecida", ou a seguir com a instrução processual e ser denunciado.

Foram consideradas também as formas de desfecho do processo. Observamos que, de maneira geral, a forma de finalização processual mais recorrente é pela prescrição (31\%), seguida da homologação da Transação Penal ${ }^{14}$ (29\%) e da denúncia ${ }^{15}$ (16\%) . No entanto, grande parte dos processos estariam sem informação ${ }^{16}(11 \%)$ por não terem ainda chegado

12 Como a pesquisadora inicialmente optou por considerar os processos a partir dos autores do fato, considera-se aqui o número de audiências por autor do fato. No entanto é cediço que em um mesmo processo pode haver mais de um réu e em consequência a audiência seria a mesma, então o Ministério Público compareceu a 12 audiências às quais os autores dos fatos não compareceram. 13 Damásio de Jesus elucida que a transação penal é um negócio entre o Ministério Público e a Defesa, possibilitando-se ao juiz, de imediato, aplicar uma pena alternativa ao autor do fato, justa para a acusação e para a defesa. (Jesus, D. E. (1995). In: V. Brega Filho, et al. orgs, (2007).

14 Considerou-se a homologação da transação penal como desfecho do processo por uma questão de tempo de pesquisa, isto porque grande parte dos processos, por serem mais recentes, não estavam tão avançados a ponto de possuir sentença extintiva de punibilidade pelo cumprimento de transação penal. No entanto, ressalva-se aqui que o processo só se finaliza com sentença extintiva de punibilidade por prescrição ou por cumprimento da TP, ou por sentença condenatória. Tanto que alguns processos da amos tra da pesquisa possuem transação penal homologada e sentença de prescrição ao mesmo tempo.

15 Mesma justificativa da nota 10 , com fundamentação referente à denúncia.

16 Os casos S/I dizem respeito aos processos em que houve audiência (precedida por conciliador ou juiz leigo) com o oferecimento da proposta da TP, mas que ainda não foram homologadas pelo Juiz. nessa fase processual. Há também aqueles que, embora com a Transação Penal homologada, vieram a prescrever (5\%).

Tabela 9. Formas de Desfecho para o Processo

\begin{tabular}{|c|c|c|}
\hline \multicolumn{3}{|l|}{ DESFECHO DO PROCESSO } \\
\hline Prescrição & 76 & $31 \%$ \\
\hline TP Homologada & 70 & $29 \%$ \\
\hline Denúncia & 40 & $17 \%$ \\
\hline Deslocamento & 3 & $1 \%$ \\
\hline Decisão homologação + Prescrição & 11 & $5 \%$ \\
\hline Denúncia + Prescrição & 7 & $3 \%$ \\
\hline Deslocamento + Prescrição & 4 & $2 \%$ \\
\hline Deslocamento + Denúncia & 4 & $2 \%$ \\
\hline Prescrição + Denúncia + Deslocamento & 1 & $0 \%$ \\
\hline S/I (sem informação) & 26 & $11 \%$ \\
\hline Total & 242 & $100 \%$ \\
\hline
\end{tabular}

Fonte: coleta de dados da pesquisa

Cada variável acima descrita foi observada de maneira particularizada para cada uma das três varas estudadas. Suprimiu-se, no entanto, as implicações das características físicas e sociais dos autores do fato e das drogas em cada Vara, tendo em vista que, como exposto acima, parecem não influenciar na escolha da transação penal e na homologação pelo juiz - motivo pelo qual foi posta a verificação nas entrevistas. Da mesma forma, dispensou-se a observação pormenorizada do momento do oferecimento da Transação Penal (se em parecer ou em audiência); e a presença do Ministério Público na audiência e do tipo de transação penal oferecida pelo MP.

Importante destacar que, pelo princípio da unicidade e indivisibilidade que regem o Ministério Público, todos os quatro promotores atuaram em processos tanto da $1^{\mathrm{a}}$, da $2^{\mathrm{a}}$ e da $3^{\mathrm{a}}$ vara.

Quando observada a quantidade de ocorrência das audiências, percebe-se que, na $1^{a}$ Vara, o número de audiências que não ocorreram (68\%) é superior ao número que ocorreram (32\%). No entanto, tanto na $2^{\mathrm{a}}$, quanto na $3^{\mathrm{a}}$ Vara, percebe-se que um maior número de audiências ocorreram (66\%) e (61\%), respectivamente, é de se notar, ainda, que a diferença é expressiva: 
Tabela 10. Realização de Audiências na $3^{a}$ Vara.

\begin{tabular}{|c|c|c|c|}
\hline \multicolumn{4}{|c|}{ AUDIÊNCIA PRELIMINAR } \\
\hline & $1^{\text {a }}$ Vara & $2^{\mathrm{a}}$ Vara & $3^{\text {a Vara }}$ \\
\hline $\begin{array}{l}\text { Audiências não ocor- } \\
\text { reram }\end{array}$ & $101(68 \%)$ & $13(34 \%)$ & $22(39 \%)$ \\
\hline $\begin{array}{l}\text { Audiências que ocor- } \\
\text { reram }\end{array}$ & $47(32 \%)$ & $25(66 \%)$ & $34(61 \%)$ \\
\hline Total $(n=242)$ & $148(100 \%)$ & $38(100 \%)$ & $56(100 \%)$ \\
\hline
\end{tabular}

Fonte: coleta de dados da pesquisa

Nota-se que houve um número maior de audiências realizadas na $2^{\mathrm{a}}$ e $3^{\mathrm{a}}$ Varas do que na $1^{\mathrm{a}}$ Vara. Percebemos que há uma maneira diferente de condução do processo em cada uma das varas. Os motivos para isso, no entanto, não foram analisados na pesquisa.

No que se refere ao desfecho do processo, tivemos que:

Tabela 11. Formas de Desfecho para o Processo na $1^{a}$ Vara.

\begin{tabular}{|c|c|c|c|}
\hline \multicolumn{4}{|c|}{ DESFECHO DO PROCESSO } \\
\hline & $1^{\mathrm{a}}$ vara & $2^{\mathrm{a}}$ vara & $3^{\mathrm{a}}$ vara \\
\hline Prescrição & $70(47 \%)$ & 0 & $6(11 \%)$ \\
\hline TP Homologada & $34(23 \%)$ & $14(37 \%)$ & $22(39 \%)$ \\
\hline Denúncia & $15(10 \%)$ & $11(29 \%)$ & $14(25 \%)$ \\
\hline Deslocamento & $2(1 \%)$ & $1(3 \%)$ & 0 \\
\hline $\begin{array}{l}\text { Decisão homologação } \\
\text { + Prescrição }\end{array}$ & $11(7 \%)$ & 0 & 0 \\
\hline Denúncia + Prescrição & $7(5 \%)$ & 0 & 0 \\
\hline $\begin{array}{l}\text { Deslocamento + Pres- } \\
\text { crição }\end{array}$ & $4(3 \%)$ & 0 & 0 \\
\hline $\begin{array}{l}\text { Deslocamento + De- } \\
\text { núncia }\end{array}$ & $4(3 \%)$ & 0 & 0 \\
\hline $\begin{array}{l}\text { Prescrição + Denúncia } \\
\text { + Deslocamento }\end{array}$ & $1(1 \%)$ & 0 & 0 \\
\hline$S / I$ & 0 & $12(32 \%)$ & $14(25 \%)$ \\
\hline Total & $\begin{array}{l}148 \\
(100 \%)\end{array}$ & $38(100 \%)$ & $56(10 \%)$ \\
\hline
\end{tabular}

Fonte: coleta de dados da pesquisa

$\mathrm{Na} 1^{\text {a }}$ Vara a maioria dos processos prescreveu (47\%), levando-se ainda em consideração que $7 \%$ dos processos, embora com a transação penal homologada, também prescreveram. Já na $2^{\text {a }}$ Vara do Sistema dos Juizados, percebe-se que nenhum dos processos prescreveu, no entanto 32\% deles está sem informação. O número de transações penais homologadas é de (37\%) e em $29 \%$ dos processos o MP denunciou.
Percebe-se que, na $3^{\text {a }}$ Vara do Sistema dos Juizados, o número de prescrição de processos é menor do que os da $1^{a}$ Vara, e maiores do que os da $2^{a}$, totalizando $11 \%$. O número de transações penais homologadas também é o mais expressivo (39\%):

A partir desses dados foi constatado que:

a. Critérios como tipo/quantidade de droga e circunstâncias sociais/raciais/de gênero parecem não influenciar na pena a ser oferecida pelo ministério público.

b. Cada promotor oferece um tipo de pena e a frequência dessas na amostra estudada está claramente relacionada à quem atuou no processo.

c. Na maioria dos processos não há participação do ministério público na audiência e as propostas de transação penal são feitas, em maioria, por parecer (manifestação escrita).

d. Em cada uma das varas os processos "caminham" de diferentes maneiras, o que ocasiona desfechos diferentes.

\section{As concepções através das entrevistas: os modos de pensar dos juizes e promotores feirenses em matéria do crime de uso de drogas}

Até o presente momento foi apresentado um caráter metodológico mais quantitativo e descritivo. Nos ativemos inicialmente aos dados observáveis nos processos de porte de drogas para consumo pessoal, descrevendo os dados relevantes os quais nos permitiram algumas percepções e constatações. A partir de agora, será apresentada a parte mais qualitativa da pesquisa. Serão demonstrados o modo como foram realizadas as entrevistas, a maneira como foram extraídas as informações dessas e as ideias que puderam ser abstraídas dos entrevistados.

\subsection{A construção das categorias}

O instrumento de investigação empírica escolhido foi a entrevista semiestruturada. O roteiro das entrevistas foi constituído primeiramente com base nos dados obtidos pela observação dos processos pesquisados e, posteriormente, por perguntas abertas que permitissem conhecer os modos de pensar dos entrevistados em relação ao crime e principalmente às penas do art. 28 da Lei $n^{\circ} 11.343 / 06$. 
Foram entrevistados 05 (cinco) dos 07 (sete) atores jurídicos que atuaram nos processos estudados na primeira etapa da pesquisa.

Como os atores envolvidos na pesquisa possuem algumas particularidades - juízes e promotores - foram criadas perguntas gerais (que valessem tanto para juízes quanto para promotores) e perguntas específicas (perguntas direcionadas aos juízes e perguntas direcionadas aos promotores). A necessidade de se fazer essa distinção se deu justamente pelas diferentes formas de atuação desses atores jurídicos: enquanto os primeiros oferecem as propostas de transação penal, os segundos homologam ou não essa proposta, sendo necessário saber, para os fins da presente pesquisa, de que forma eram feitos esses procedimentos:

\section{ROTEIRO ENTREVISTA PROMOTOR}

I. Qual (is) os critérios que V. Ex utiliza para a definição da proposta de Transação Penal a ser oferecida?

II. Como é oferecida a Transação Penal, em parecer ou em audiência? Por que? Quais os benefícios e as dificuldades de se utilizar de uma maneira ou de outra?

III. Além das penas do art. 28 da Lei $n^{\circ} 11.343 / 06$, V. Ex ${ }^{a}$ utiliza outros tipos de penas alternativas? Qual(is)? Por que?

IV. Caso o autor não compareça para audiência preliminar, qual o procedimento adotado por V. Ex ${ }^{\mathrm{a}}$ ?

V. Como V. Ex encara a importância da negociação da Transação Penal no Processo?

VI. Como V. Ex ${ }^{a}$ caracteriza as penas do art. $28 \mathrm{da}$ Lei de Drogas?

VII. Para V. Ex ${ }^{a}$, quais as repercussões das penas alternativas do art.28 da Lei de Drogas para o mundo jurídico?

VIII. Para V. Ex ${ }^{a}$, quais as repercussões da aplicação das penas alternativas do art. 28 para sociedade e para o usuário-infrator?

\section{ROTEIRO ENTREVISTA JUIZ}

I. V. Ex a costuma participar das audiências preliminares? Como V. Ex ${ }^{a}$ considera a participação do juiz de direito na audiência preliminar?

II. Como é feito o processo de homologação das Transações Penais?
III. Caso o autor do fato não compareça para a audiência preliminar, qual o procedimento adotado por V. Ex ${ }^{a}$ ?

IV. Como V. Exa encara a importância da negociação da Transação Penal no Processo?

V. Como V. Ex ${ }^{a}$ caracteriza as penas do art. $28 \mathrm{da}$ Lei de Drogas?

VI. Para V. Exa , quais as repercussões das penas alternativas do art.28 da Lei de Drogas para o mundo jurídico?

VII. Para V. Ex a quais as repercussões da aplicação das penas do art. 28 para sociedade e para o usuário-infrator?

As primeiras perguntas, tanto do roteiro de entrevista do promotor quanto do roteiro de entrevista do juiz, possuem a intenção de saber e entender como esses atores jurídicos atuam nos processos. Embora já se tivesse uma noção da maneira dessa atuação a partir dos dados colhidos na primeira fase da pesquisa, esse momento foi necessário para se ter conhecimento da importância que esses atores sociais atribuem a cada etapa da atuação deles no processo.

A gradação das perguntas foi uma etapa necessária para se chegar às perguntas mais diretas, sobre as penas do art. 28 da Lei de drogas. Buscou-se, portanto, saber quais são as concepções dos atores jurídicos a partir da compreensão - da maneira mais ampla possível - sobre a forma de pensar deles quanto ao crime e às penas do art. 28 e a possibilidade destas representarem mudanças para o mundo jurídico.

Após as entrevistas foi o momento de transcrição e análise do material obtido que, conforme já explicitado na metodologia, foi realizada seguindo o método da Teoria Fundamentada nos Dados (TFD).

Cabe ressaltar que pelo método da TFD o processo de leitura do material empírico deve ser constante e repetida nas diversas fases da análise. Assim, a cada releitura do material é possível a descoberta de uma nova categoria até esta atingir a estabilização por meio da saturação, quando as observações apenas suscitarem exemplos que componham as categorias já existentes.

Dessa forma, algumas categorias foram extraídas diretamente das perguntas feitas aos atores e outras foram 
criadas a partir das respostas espontâneas dos mesmos:

1. Critérios utilizados pelos promotores para oferecimento da Transação Penal;

2. Envolvimento do ator no processo, com as subcategorias:

// Modo de oferecimento da TP,

// Motivos utilizados pelos promotores para oferecimento em parecer;

// Participação do juiz na audiência preliminar,

// Importância da participação do juiz de direito na audiência preliminar; Processo de homologação das transações penais;

// Negociação da transação penal;

3. Percepção da Transação Penal No Processo;

4. Natureza e caráter das penas do art. 28 da Lei de drogas com as subcategorias: Natureza Das Penas Do Art. 28 Da Lei De Drogas;

5. Efetividade e Eficácia das Penas do art. 28;

6. Repercussões das penas do art. 28 para o mundo jurídico;

7. Repercussões das penas do art. 28 para a sociedade e para o infrator;

8. $\quad$ Rigor penal das penas do art. 28 da Lei;

9. As repercussões das penas alternativas para o mundo jurídico;

10. Figura do legislador na tipificação do crime.

\subsection{Análise dos discursos à luz das categorias}

Passamos agora para a análise das entrevistas, relacionando as categorias criadas com as falas dos atores. Aqui, serão apresentadas as ideias que puderam ser abstraídas das falas dos atores entrevistados, sem atribuição direta de quem fala. No entanto, será possível notar os contrastes que ora aparecem em virtude das semelhanças e diferenças das ideias de cada entrevistado.

1. Critérios utilizados pelos promotores para oferecimento de TP

Através das respostas dos atores foi possível perceber que de maneira geral os promotores trabalham com a ideia de eficácia de pena como critério de oferecimento da proposta de transação penal:

"A medida do inciso III é mais esclarecedora, não há aspecto punitivo no juizado, sendo a mais con- sentânea das três penas.(...) Não há a interferência de outros critérios como quantidade de drogas. (...) É um critério de eficácia da pena, tendo em vista que a advertência tem eficácia nula, a prestação de serviços à comunidade é mais punitiva e a medida de comparecimento a cursos e programas educativos é mais eficaz".

Nota-se que, como sugerido anteriormente, não aparece no material coletado a interferência de critérios como tipo e quantidade de droga, nem gênero, cor, condição social do autor do fato para o estabelecimento da proposta, confirmando o que preliminarmente foi observado na fase quantitativa da pesquisa.

\section{Envolvimento do ator com o processo}

Essa categoria foi elaborada com o intuito de saber a forma como esses atores jurídicos oferecem a transação penal no processo e a importância que eles atribuem a sua participação efetiva nas audiências.

Os promotores entrevistados oferecem as transações penais por meio de manifestação escrita. Os motivos para tanto, para alguns, perpassam pela otimização do tempo do promotor de justiça, celeridade e racionalização de recursos. Apenas na fala um dos entrevistados apareceu a justificativa de o autor do fato ter o direito de ter conhecimento prévio sobre o oferecimento da transação penal:

"é encaminhada uma manifestação pedindo pra certificar sobre os antecedentes e, no caso de não ter, já é proposta a transação penal. (...) na prática o ministério público recebe o termo circunstanciado e já manda o termo circunstanciado para o juizado com a proposta".

"é escolhida essa medida porque ganha-se tempo, é mais célere, para já chegar na audiência e ter a transação penal. Tem como benefício a celeridade, a racionalização de recursos”.

"Porque no momento o noticiado (...) é intimado para comparecer em audiência, ele tem ciência de que já tem uma proposta oferecida, então ele já tem uma proposta, já vai sabendo que tem aquela proposta ou se insurgir, dizendo que não quer aquela proposta". 
Quanto à participação na audiência preliminar, para a maioria dos entrevistados, há a ideia de que não é necessária da presença do promotor de justiça e do juiz de direito. Para estes, a proposta de TP, já oferecida no processo, seria apresentada ao autor do fato por meio do conciliador e a negociação da transação penal seria inexistente ou limitada.

“Não, na audiência preliminar é só entre autor do fato e conciliador. A princípio não há necessidade de o juiz de direito participar dessas audiências porque ela já tem um fim, que é o propósito da conciliação, mediação".

"não existe negociação numa audiência criminal, é uma aceitação ou não, 'ou você aceita ou responde ao processo'. É uma proposta fechada que o ministério público faz, na qual a parte deve aceitar ou não, se não aceitar é denunciado".

"As possibilidades de negociação são muito poucas, assim o autor do fato não teria muitas opções para a escolha, no caso a negociação restaria mitigada".

Um dos entrevistados demonstrou o entendimento quanto a necessidade de participação na audiência preliminar e de que este é o momento de se negociar a transação penal, como uma maneira de humanização do processo penal:

"e nessa audiência é feita a proposta, a gente explica quais são as consequências da aceitação, da não aceitação, qual o período, se fosse um caso, por exemplo, de prestação de serviços à comunidade, durante tanto tempo, por tal período, toda a explicação de como é, é feito ali, é necessário que tenha um advogado, óbvio, pelo direito de defesa dele, então o advogado concorda ou não juntamente com ele, com a questão dos termos da proposta. Pessoalmente a gente sempre teve a oportunidade de ouvir o outro lado".

\section{Percepção da Transação Penal no Processo}

Esta terceira categoria foi criada a partir das falas dos atores ao longo das entrevistas que, de forma espontânea, pontuaram qual a visão deles sobre a transação penal no processo. Para um deles, a transação penal foi questionada como uma forma de flexibiliza- ção de garantias, já que ainda não há processo para o autor do fato se defender. No entanto, para a maioria dos entrevistados, a transação penal é encarada como um benefício e uma oportunidade para o autor do fato, assim como a otimização do judiciário:

"é interessante porque ela (a lei 9.099/95) lida com um processo, sem você ter um processo penal, dai porque questionável se você de alguma forma não flexibiliza garantias, porque você se defende de um processo, de uma ação, de uma ação que inicia-se com uma denúncia, na transação penal, no Jecrim, você não tem uma denúncia, você tem um termo circunstanciado".

“(...) homologado, a gente tem o cuidado de verificar se o autor do fato tem antecedentes criminais, se ele já fez jus a homologação, porque se ele já respondeu a um processo, um termo circunstanciado em que ele teve o benefício da transação penal, ele fica durante um período sem poder renovar esse benefício. Então tem um prazo de 05 cinco anos em que ele não pode ter um novo benefício da transação penal”.

Pudemos perceber que em algumas entrevistas parecia haver uma inclinação para o convencimento do autor do fato quanto à aceitação da transação penal e que, embora alguns entrevistados tracem como um benefício para o usuário infrator, outros apresentam como um benefício também para o judiciário, já que não teria o elevado custo de se prosseguir com o processo.

\section{Natureza e caráter das penas do art. 28 da Lei de Drogas}

A partir dessa categoria passamos a observar mais direcionadamente a visão que os entrevistados possuem sobre as penas do art. 28 da lei de drogas.

As respostas divergem entre os entrevistados, passando: i) pela consideração das penas do art. 28 como medidas administrativas que são tratadas, porém, no âmbito do direito penal; ii) como penas que possuem resposta penal insignificante e não possuem efetividade no plano concreto, já que em caso de descumprimento não há a previsão de "penas verdadeiras"; iii) e como penas não encarceradoras, benéficas para o mundo jurídico por prever sanções diversas à pri- 
são e com a função corretiva, de recuperar o usuário-infrator e trazê-lo para a "realidade":

“Como não há disposição sobre detenção, reclusão, seria um ilícito penal que encontra sanção no âmbito do Direito Administrativo".

"acredito que as penas do art. 28 não tenham efetividade alguma no plano concreto, porque em caso de descumprimento não há nenhuma consequência prática para o autor, porque não há a possibilidade de aplicar uma pena privativa de liberdade em momento algum, não há coercibilidade da medida. As penas, na verdade, acabam se configurando como conselhos aos quais o autor do fato deveria seguir, sendo melhor descriminalizar ou criminalizar com penas verdadeiras".

"para o modelo que nós temos de legislação, não deixa de ser uma evolução, então é muito mais alentador imaginar que o legislador em 2006 conseguiu ao menos imaginar que essas pessoas não precisam ter o cárcere como resposta".

A questão que primeiramente se traz é que, caso o autor do fato descumpra a sanção a ele imposta, não é previsto pela legislação uma "ação coercitiva" do Estado para obrigá-lo a cumprir, como no caso de uma previsão de pena privativa de liberdade, mesmo que em último momento. A intenção é, portanto, a certeza quanto à punição.

Foi muito marcante, nas entrevistas, a noção dos entrevistados quanto à descriminalização ou não, por um lado, e da despenalização ou não do crime e das penas do art. 28, por outro. Notamos que, segundo o entendimento dos entrevistados, o fato de o art. 28 da lei de drogas não prever em nenhum momento a privação da liberdade como sanção para o crime de uso de drogas, desqualificaria a conduta como crime e desqualificaria os três incisos do art. 28 como pena:

"é claro que houve uma descriminalização, porque não houve previsão de detenção, reclusão, prisão, internação compulsória, e em sede de condenação, seja em sede de transação penal”.

"como lidar com essa nova possibilidade dos usuários de drogas que a gente não tem a perspectiva de uma pena".

Com isso, temos que a questão da descriminalização e da despenalização da conduta tipificada no art. 28 da lei de drogas é muito marcante entre os atores jurídicos entrevistados. Mesmo passados mais de 10 anos da edição da lei, quando houve acaloradas discussões doutrinárias e jurisprudenciais, é visível que este ponto ainda não se encontra estabilizado entre os atores jurídicos entrevistados envolvidos na aplicação do art. 28 da lei de drogas em Feira de Santana.

É possível identificar ainda que esta "confusão" quanto à definição de crime e de pena é sempre condicionada à previsão ou não da privação de liberdade como sanção para o crime. Mesmo para aqueles atores que consideram as penas do art. 28 como "penas verdadeiras" e com resposta penal relevante, há uma dificuldade de se conceituar tais medidas, ao menos de forma imediata, como pena. Em outras palavras, o modo como compreendem e o sentido que atribuem às penas gira em torno da privação de liberdade, que, por sua vez, condiciona a existência ou não do crime.

Vale dizer, aqui, que nessa leitura, os próprios atores jurídicos encontram-se aprisionados pelo conceito de pena que a atrela à prisão.

\section{Eficácia e Efetividade das Penas do art. 28}

Essa categoria surgiu a partir das falas dos atores no decorrer das entrevistas, de forma espontânea, ou seja, sem nenhuma pergunta direta.

Nos pareceu que para os entrevistados a efetividade e a eficácia das penas do art. 28 está diretamente ligada a existência de uma coerção - para uns -, e fiscalização - para outros -, dos instrumentos que garantam a certeza do cumprimento da medida:

"acredito que as penas do art. 28 não tenham efetividade alguma no plano concreto, porque em caso de descumprimento não há nenhuma consequência prática para o autor".

"eu acho que uma das coisas que mais reforça o não acreditar na eficácia dessas penas é a falta de estrutura e fiscalização também, porque se a gente 
for pensar, 'restrição de final de semana', ok, você diz que você não vai poder, quem vai fiscalizar isso? o cumprimento a entidades tal, quem vai fiscalizar que ele está indo".

6. Repercussões das penas do art. 28 para o mundo jurídico

Buscou-se saber como esses atores veem os efeitos da previsão legal de uma pena não privativa de liberdade na cominação principal para um crime.

Percebemos uma divergência nas respostas dos atores quanto a esse ponto. Enquanto em algumas entrevistas observamos a noção de que não houve um avanço em matéria de penas pelo fato de que a resposta penal prevista seria insignificante, em outras apareceu a ideia de que o estabelecimento das penas do art. $28 \mathrm{da}$ lei de drogas repercutem no mundo jurídico de modo que é uma forma de o direito penal dar uma resposta ao crime, mas sem o elevado custo do cárcere:

"No caso especifico da lei de drogas a lei não dá a resposta, em alguns casos, quando não há a TP há a denúncia, o efeito prático é somente potencial de gerar (...) a resposta penal é insignificante, qual a opção do legislador: fingir que está punindo ou descriminalizar".

"Bom para o mundo jurídico foi uma alternativa que se teve para que despenalizando para aqueles menores, aqueles crimes de menor potencial possa ser dada uma resposta do judiciário, mas sem o custo tão grande como é o de manter o preso em cárcere privado. Então a pena alternativa tem esse benefício em não trazer esse custo tão grande como é o de manutenção do preso".

Notamos que na visão desses primeiros entrevistados é melhor tirar a conduta de porte de drogas para consumo pessoal do rol dos crimes a punir com as penas que estão estabelecidas, tendo em vista que estas tornam o direito penal sem efetividade. A preocupação com o direito penal em detrimento do crime é clara, é como se atribuir ao Direito Penal uma pena que não seja "verdadeira" fosse um malefício para a sua efetividade, devendo-se, portanto, descriminalizar logo para "cortar o mal pela raiz".
7. Repercussões das penas do art. 28 para a sociedade e para o infrator

Essa categoria objetivou descobrir como os entrevistados enxergam a efetividade das penas para o usuário-infrator e para a sociedade.

Nesse ponto específico, pudemos perceber que entre a totalidade dos entrevistados, apareceu a ideia de que as penas do art. 28 são positivas se influenciar positivamente na vida do usuário e repercutem a depender da pena aplicada. No entanto, notamos a preocupação bem marcante que a previsão de tais penas poderia ensejar para a sociedade uma visão de injustiça e impunidade:

"se ele cumprir uma das medidas previstas em lei e, inclusive, deixar a droga, participando de programas educativos e até dando palestra contra o uso das drogas e os efeitos nocivos, é claro que há um efeito positivo da pena sobre a sociedade. Mas insisto que se ele não cumprir nenhuma das medidas do art. 28 e voluntariamente não há nenhuma consequência penal e moral, pode passar a impressão para a sociedade de impunidade e ineficácia das medidas".

Identificamos, com isso, que o discurso de 'dar uma resposta à sociedade' por um mal cometido pelo infrator é bem presente e se configura como um dos limitadores a credibilizar as penas alternativas à prisão como penas principais ao crime.

\section{Rigor penal das penas do art. 28 da Lei de Drogas} O rigor de cada uma das penas constantes nos três incisos do art. 28 da lei de drogas também foi bem pontuado entre todos os promotores entrevistados. Percebemos a necessidade de se propor penas coerentes com o crime e com a realidade do autor do fato. Para estes, a pena de advertência, totalmente dispensável e sem sentido, não deveria ser atribuição do juiz e promotor de justiça. Já a prestação de serviços à comunidade não seria uma resposta adequada ao crime de porte de drogas para consumo pessoal, pois não tem relação lógica com o crime e por isso, seria mera pena retributiva. A pena do inciso III, por sua vez, seria a mais eficaz, por ter relação com o crime e uma repercussão mais positiva para o usuário: 
"advertência nunca é proposta, porque informação está disponivel para todos e eu não vejo eficácia numa medida de advertência. A medida prioritariamente formulada é a do inciso III, a prestação de serviços à comunidade é como se fosse subsidiária, caso o autor do fato não aceite a medida de comparecimento a cursos e programas educativos. A medida do inciso III é mais esclarecedora, não há aspecto punitivo no juizado, sendo a mais consentânea das três penas (...). A prestação de serviços à comunidade é mais punitiva".

9. As repercussões das penas alternativas para o mundo jurídico

Embora não tenha sido objeto diretamente de pergunta, em todas as falas foi possível identificar a opinião dos entrevistados quanto às penas alternativas de um modo geral. As penas alternativas para alguns foram consideradas importantes, mais efetivas para a ressocialização; para outros, porém, devem ser utilizadas a depender do crime ao qual se aplica e quando há uma garantia de cumprimento (por meio da coerção).

"Existe na sociedade brasileira muito direito penal - direito penal simbólico, acionado para tudo, perdendo a força de contenção, a ultima ratio do direito penal fica mitigada. As penas alternativas são maravilhosas, no entanto são aplicadas para crimes que nem deveriam ser crimes, como os de menor potencial ofensivo (ameaça, lesão leve, vias de fato, injúria, difamação...). Crimes de ação privada, crimes contra o patrimônio e que não envolvam violência ou grave ameaça, crimes com possibilidade de substituição da pena privativa de liberdade para as restritivas de direito não deveriam ser tratadas pela justiça comum criminal e sim pelos juizados".

"Uma pena alternativa de prestações serviços à comunidade num crime de lesões corporais, por exemplo, se o autor do fato não cumprir, o processo volta para ele cumprir outra pena coercitivamente. O mesmo não acontece com as penas do art. $28 \mathrm{da}$ lei de drogas".

\section{Figura do legislador na tipificação do crime}

Essa categoria foi criada por termos identificado na fala dos atores a menção quanto à figura do legislador de 2006 no momento da tipificação do crime do art. 28. Foi possível perceber, nas entrevistas, uma certa insatisfação com essa figura legislativa: i) ou por este ter tipificado a conduta de porte de drogas para consumo pessoal como crime; ii) ou por este ter estabelecido penas "sem coercibilidade" como respostas penais para um crime; iii) ou por este ter estabelecido a conduta de porte de drogas para consumo pessoal como crime e cominado penas diversas à prisão.

Todos os entrevistados trataram como se, na verdade, tivesse havido uma "confusão do legislador" na tipificação do crime do art. 28 ou uma falta de coragem desta figura para descriminalizar a conduta de uso das drogas, optando-se, por isso, pela imposição de penas diversas à prisão, como uma forma de compensação à sua omissão:

"A gente sempre comenta que o legislador não teve talvez a coragem necessária de enfrentar a questão de descriminalizar o uso da droga, então ele manteve um crime, o art. 28 da lei 11.343/06, mas ao mesmo tempo ele não previu uma pena como a gente tem, nos moldes, no padrão da pena restritiva de liberdade da legislação anterior, por exemplo".

Foi possivel observar a estranheza com a qual os entrevistados enxergam as penas do art. 28 da Lei de Drogas. Todos acreditam que, na verdade, ou o legislador caiu em equívoco (confusão) ou foi uma 'medida estratégica' (uma saída para não descriminalizar a conduta), ao instituir como penas a advertência, prestação de serviços à comunidade e medidas de comparecimento a cursos e programas educativos.

No entanto, ao mesmo tempo que dizem não concordar com o posicionamento "do legislador" na tipificação do crime do art. 28, percebemos que os mesmos agem de acordo com a "vontade do legislador" em relação ao crime e às penas do art. 28 :

“(...) essa sensibilidade no sentido da gente ter que buscar alguma coisa que tivesse mais, que pudesse respeitar aquela opção daquele indivíduo no uso da droga, mas que também contemplasse o que a legislação disse, a legislação disse "olha, não disse que não é mais crime, continua sendo crime, agora eu disse que a resposta a isso vai ser diferenciada". 
Sobre essa "confusão" dos próprios atores jurídicos entre aplicar de acordo com as suas concepções e aplicar de acordo com a "vontade do legislador" é importante nos remeter ao argumento para o qual Álvaro Pires (2011) nos chama atenção:

o próprio sistema de direito enxerga a legislação como 'exprimindo a vontade do legislador' e como uma 'fonte do direito', ou seja, como uma fonte para fazer emergir um direito pelo direito (...). Mas, ao mesmo tempo, a teoria dos sistemas lembra que é o sistema de direito que determina, no contexto de suas comunicações e decisões, qual é, efetivamente, em cada caso concreto, essa vontade do legislador.(p. 312)

De acordo com a teoria dos sistemas, as estruturas podem mudar em razão de sua relação com o tempo. Segundo Álvaro Pires as estruturas mais exigentes são as estruturas de pensamento centrais dos sistemas sociais, que são as estruturas do sistema cognitvo ou de reflexão do próprio sistema de direito (2011, p. 309-310). Essa estrutura teria maior condensação de sentido (dimensão histórico-cultural), duraria mais no tempo e teria maior capacidade e resistência à perturbação. É quando os ‘aplicadores do direito' atuam de forma diversa ao estabelecido legislativamente, o que ocasiona uma inovação no plano concreto.

Em outras palavras, a teoria dos sistema nos mostra que, na verdade, o sistema de direito utiliza - de forma voluntária ou involuntária, "a vontade do legislador” para justificar as suas próprias ações dentro do processo. Portanto, embora os atores jurídicos entrevistados nessa pesquisa digam pensar de forma diversa à lei, justificam o seu modo de aplicação na própria lei de drogas, cada um de acordo com a maneira que pensa ser mais coerente.

\subsection{Análise geral das categorias}

Como já explicitado, o método da TFD permite que a partir dos dados sejam formuladas hipóteses, as quais podem dialogar com as teorias já existentes.

De início, pudemos perceber que há entre os atores uma preocupação muito grande com a otimização e racionalização do processo, do tempo do promotor de justiça e do judiciário. A preocupação com o autor do fato e com as possibilidades de ele cumprir a transação penal só apareceu na fala de um dos entrevistados. A negociação da transação penal, por sua vez, que deveria ser um momento importante no processo - quando o autor do fato e o titular da ação penal, com supervisão do juiz, negociariam a proposta oferecida pelo ministério público, buscando as possibilidades de o autor do fato cumprir a medida -, não é efetivada. Apenas um ator considerou participar das audiências preliminares, reforçando a importância desse momento para o autor do fato e para o judiciário. Assim, a negociação da transação penal no processo acaba sendo inexistente, um meio apenas de dizer ao autor do fato: "aceite ou será denunciado".

Em contrapartida a essa postura, a maioria dos entrevistados não consideram as penas do art. 28 da lei de drogas como "penas verdadeiras". Isto porque essas penas seriam "desprovidas de coercibilidade", possuiriam “resposta penal insignificante", e não seriam, portanto, penas pelo fato de não se incidir a detenção ou reclusão.

É possível notar que, em um primeiro momento, a maioria dos atores demonstra não se importar com o cumprimento da pena proposta pelo autor do fato (não participação na audiência preliminar). No entanto, em um segundo momento, para esses, o cumprimento das penas do art. 28 passa a ser critério imprescindível para a eficácia da medida. A questão de que não há uma sanção efetiva (punida com prisão) em caso de descumprimento é a grande justificativa para não se considerar as penas do art. 28 como penas de fato. Temos, portanto, que a problemática não diz respeito ao cumprimento ou não da pena aplicada, mas sim a certeza da punição estar lastreada numa pena aflitiva, que cause algum tipo de sofrimento para o infrator.

A discussão sobre a despenalização ou não e a descriminalização ou não do crime de porte de drogas para consumo pessoal esteve bem presente na fala dos entrevistado e demonstra que a questão ainda não se encontra estabilizada entre os mesmos. Percebemos, também, que o conceito de pena para os atores está intrinsecamente ligado à previsão de privação da liberdade e o conceito de crime está inter-relacionado com a pena ao qual se aplica. Os atores jurídicos, ao menos em um primeiro momento, afirmaram ter ha- 
vido uma despenalização para a conduta do uso de drogas, mesmo que depois fosse reconhecido que as penas do art. 28 possuem um caráter penalizador. Em outras palavras, a ideia que perpassa os entrevistados é a de que não há crime sem pena que inflija dor e sofrimento ao corpo do infrator.

A fiscalização e a existência de instrumentos que garantem o cumprimento da medida pareceu um critério necessário para a eficácia e efetividade das penas alternativas.

Para a maioria, não foi vislumbrado que as penas do art. 28 da Lei de Drogas foi um avanço para o direito penal. Pelo contrário. Para alguns, as penas de advertência, prestação de serviços à comunidade e medidas de comparecimento a cursos e programas educativos, na verdade, teriam efeitos negativos no âmbito do direito penal porque traz a este um aspecto de inefetividade, de resposta insignificante. Ou seja, a imposição de penas como as do art. 28 da Lei de Drogas descredibilizaria o Direito Penal. Apenas dois dos cinco entrevistados pontuaram que estas penas seriam um avanço para o direito penal em matéria de definição de penas por não prever o cárcere em nenhum momento.

Foi possível notar, ainda, que todos os entrevistados consideram as penas do art. 28 benéficas para o autor do fato se houver realmente uma mudança positiva de comportamento deste, ou seja, há entre os atores uma visão de correção do indivíduo. No entanto, embora pontuem esse potencial benefício das penas do art. 28 , a maioria chama atenção que a sociedade e mesmo as instituições jurídicas não estão preparadas para oferecer como resposta a um crime penas alternativas à prisão, demonstrando que estas podem causar na sociedade uma sensação de injustiça e impunidade.

Percebemos que a maioria dos entrevistados legitimam ou não as penas do art. 28 através do 'rigor' que são atribuídos a elas. Ou seja, as penas só passam a ser oferecidas caso entendam que possuem o rigor necessário para a reprimenda, no entanto, esta "avaliação" não é feita para cada caso concreto e sim de forma generalizada de acordo com o que acreditam ser, de modo geral, "mais eficaz".

Portanto, em síntese, observamos que a imposição de penas alternativas para crimes seria: i) uma opção mais benéfica para a ressocialização do infrator, no entanto somente ii) a depender do crime (em regra para crimes mais brandos), iii) válida quando houvesse uma sanção em caso de descumprimento (punição pela privação da liberdade), sendo que há a necessidade de se iv) trabalhar com a sociedade a aceitação a esses tipos de penas e também os próprios atores jurídicos aceitar as alternativas ao cárcere como penas, v) devendo o rigor penal ser validado por aquele que a aplica.

Por fim, observamos uma tendência por parte dos entrevistados de problematizar a previsão de uma conduta a qual se prevê penas alternativas como um crime. No entanto, mesmo sendo contrários e estranhos a essa opção legislativa atuam em conformidade com ela.

Nessa perspectiva, parece que a grande questão que envolve as discussões sobre o art. 28 não é o uso ser criminalizado ou não, mas sim as penas que são atribuídas a este crime.

Todos os atores jurídicos entrevistados demonstraram considerar que o uso de drogas não deveria ser crime, que é uma "questão de saúde pública", que está relacionado à intimidade do indivíduo. No entanto, quando o legislador estabeleceu como penas principais e únicas para o crime de uso de drogas a advertência, a prestação de serviços à comunidade, e as medidas de comparecimento a cursos e programas educativos, incidiu em "confusão legislativa", em "falta de coragem para descriminalizar, optando-se por despenalizar". É como se as penas tivessem sido imputadas a este crime por erro, afinal, como - DIREITO PENAL poderia prever penas alternativas como respostas principais para crimes?

Diante de todo o exposto, é possível dizer que as concepções dos atores jurídicos feirenses envolvidos no enfrentamento do crime de uso de drogas ainda revestem-se do manto da racionalidade penal moderna (RPM). A estrutura sinédoque apontada por Pires (2004) se encontra bem presente na concepção dos entrevistados. A definição do crime (todo) pela pena aflitiva (parte), os faz pensar que um esteja obrigatoriamente atrelado ao outro, razão pela qual considerar as penas do art. 28 da lei de drogas como verdadeiras penas é difícil, para uns e mesmo impossível para outros. 
Percebemos que embora as penas do art. 28 sejam utilizadas pelos atores jurídicos conforme estabelece a legislação, o sistema de pensamento que parece dominar o sistema de direito entre os entrevistados ainda é o da racionalidade penal moderna, não sendo o novo dispositivo capaz de mobilizar suficientemente uma mudança de estrutura do pensamento penal no sítio pesquisado.

No entanto, não podemos aqui ignorar algumas posturas positivas que se apresentaram no decorrer da pesquisa. Diante de uma maioria de atores que não se faz presente nas audiências preliminares e, ainda, consideram esta participação desnecessária, tivemos a efetiva participação de um dos atores na audiência preliminar e na negociação da transação penal, considerando estas como formas importantes de se humanizar o processo penal. Observamos, da parte de alguns atores, que as penas alternativas podem ser pensadas como respostas que diminuam o elevado custo do cárcere para o judiciário e os efeitos negativos deste para o infrator. E ainda identificamos perspectivas de que as penas alternativas podem ser um benefício para o infrator caso haja mudanças positivas na vida deste, o que, embora se apresente como uma visão corretiva, não deixa de ser uma justificativa para reduzir os efeitos negativos da pena de prisão.

Constatamos, assim, que embora a estrutura de resposta penal pelas penas aflitivas ainda domine, observamos que alguns elementos indicam a apresentação de novos horizontes na concepção tradicional da pena. A legislação de drogas oferece uma abertura suficiente para se pensar penas de forma diversa ao cárcere e humanização do processo penal. Para isso, necessário, portanto, efetivar essas medidas e multiplicar as ações ‘inovadoras' já existentes.

\section{Considerações finais}

A novidade penal trazida pela Lei $n^{0} 11.343 / 06$ suscitou grandes debates e reflexões por instituir como sanção para os usuários de drogas penas alternativas ao cárcere e à multa. Além desse polêmico dispositivo, a lei conferiu especial atenção ao usuário que passou a ser julgado no âmbito dos juizados especiais criminais.
Com o objetivo de compreender como pensam os atores jurídicos envolvidos no enfrentamento do crime de uso de drogas, observamos o desenvolvimento desses processos na Comarca de Feira de Santana e buscamos estudar como lidam esses atores com as penas estabelecidas. Através da maneira como atuam no processo, da importância que atribuem às suas atuações, das penas que aplicam e de como consideram as penas do art. 28 da Lei de Drogas, observamos que a Racionalidade Penal Moderna ainda reveste o sistema de pensamento dos juízes e promotores feirenses envolvidos no enfretamento ao crime de uso de drogas. O conceito do crime definido pela pena junto ao de pena definida pela privação da liberdade é tão enraizado no pensamento penal que constitui o grande obstáculo à alteração do sistema de pensamento, por um lado, e à proposta de se estabelecer respostas penais diversas ao cárcere, por outro.

Assim, a pesquisa indica que a semente plantada pela alteração legislativa em 2006 ainda não germinou, necessitando, para tanto, ser regada de debates e discussões que proporcionem questionamentos para o sistema de pensamento atual e o estímulo à previsão de penas alternativas à pena de prisão, entendidas como principais respostas para os crimes.

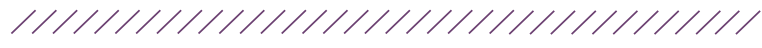




\section{Referências}

Lei $n^{\circ} 11.343$ de 23 de Agosto de 2006 (2006). Institui - Sistema Nacional de Políticas Públicas sobre Drogas - Sisnad; prescreve medidas para prevenção do uso indevido, atenção e reinserção social de usuários e dependentes de drogas; estabelece normas para repressão à produção não autorizada e ao tráfico ilícito de drogas; define crimes e dá outras providências. Brasília, DF, 08 de out. de 2006. Disponivel em: <http://www.planalto. gov.br/ccivil_03/_ato2004-2006/2006/lei/111343. htm>. Acesso em 25 jan. 2016.

Campos, M. S. (2015, janeiro). Entre doentes e bandidos: a tramitação da lei de drogas ( $\left.n^{\circ} 11.343 / 2006\right)$ no Congresso Nacional. Revista de Estudos Empíricos em Direito, vol. 2, pp. 156-173.

Capez, F. (2006). A Nova Lei de Tóxicos: Modificações Legais Relativas à Figura do Usuário. Revista Magister de Direito Penal e Processual Penal, nº 14, p. 67.

Cappi, R. (2014, janeiro). Pensando As Respostas Estatais Às Condutas Criminalizadas: um estudo empírico dos debates parlamentares sobre a redução da maioridade penal (1993 - 2010). Revista de Estudos Empíricos em Direito, Vol. 1, n 1, pp. 10-27.

Departamento Penitenciário Nacional (2014). Levantamento Nacional de Informações Penitenciárias Infopen. Recuperado em 29 de setembro de 2016, de <http://www.justica.gov.br/noticias/mj-divulgara-novo-relatorio-do-infopen-nesta-terca-feira/ relatorio-depen-versao-web.pdf>.

Deus, C. C. (2013). A aplicação das alternativas penais aos usuários ou dependentes de drogas: repercussões quanto ao acesso à justiça. Dissertação (Mestrado) - Programa de Pós-Graduação em Serviço Social, Faculdade de Serviço Social, PUCRS. Porto Alegre - RS .

Diretoria De Estudos E Políticas Do Estado, Das Instituições E Da Democracia (2014). A Aplicação de Penas e Medidas Alternativas: Relatório de Pesquisa - Sumário Executivo. Recuperado em 29 de setembro de 2016, de <http://www.ipea.gov. br/agencia/images/stories/PDFs/relatoriopesquisa/150325_relatorio_aplicacao_penas.pdf>.

Dubé, R. Éléments de théorie sur les commissions de réforme du droit et l'innovation cognitive en matière de justice pénale: contributions conceptuelles de Michel Foucault et de Niklas Luhmann (2007, Setembro 28). Champ Pénal. Recuperado em 16 de julho de 2015, de http://champpenal. revues.org/694.

Fórum Brasileiro De Segurança Pública (2015). Anuário Brasileiro de Segurança Pública. Recuperado e, 14 de fevereiro de 2016, de <http://www.forumseguranca.org.br/storage/download//anuario_2015.retificado_.pdf>.

Gomes, L. F. et. al. (2006). Nova lei de Drogas comentada. São Paulo. Revista dos Tribunais, p. 100.

Jesus, D. E. (1995). Lei dos Juizados Especiais Criminais anotada. São Paulo, p. 62. In: BREGA FILHO, V., et al. orgs, A Nova Lei de tóxicos: Usuários e Dependentes - Descriminalização, Transação Penal e Retroatividade Benéfica (2007). Revista Magister de Direito Penal e Processual Penal, n 16, p.20.

Karam, M. L. (2015). Legalização das Drogas. (1a ed.) São Paulo: Estúdio Editores. Com, - Coleção Para Entender Direito.

Lins, E.(2009). A nova lei de drogas e o usuário: a emergência de uma política pautada na prevenção, na redução de danos, assistência e na reinserção social. In: A. Nery Filho, et al. orgs. Toxicomanias: incidências clínicas e socioantropológicas. Salvador: EDUFBA; Salvador: CETAD, pp. 243-267.

Pinheiro, N. T. Justiça Restaurativa E Justiça Juvenil Em Feira De Santana: Desvendando Os Modos De Pensar Dos Atores. Trabalho de Conclusão de Curso (Graduação). Universidade Estadual de Feira de Santana, Feira de Santana, BA, BRA.

Pires, A. P.; Cauchie, J. (2011, Janeiro-Junho). Um Caso De Inovação "Acidental" Em Matéria De Penas: A Lei Brasileira De Drogas. Revista Direito GV, São Paulo, n.13,pp. 299-329.

Pires, A. P. (2004). Racionalidade penal moderna, o Público e os Direitos Humanos. Novos Estudos, n. 68. São Paulo: CEBRAP, pp. 39-60.

Rocha, O. O. (2008). A Lei $n^{\circ} 11.343 / 2006$ e suas inovações no âmbito penal ao usuário de drogas. $51 \mathrm{f}$. Trabalho de Conclusão de Curso (Graduação), Faculdade de Ciências Sociais e Tecnológicas - FACITEC, Taguatinga, DF, BRA.

Ruquoy, D. (1997). Práticas e Métodos em Investigações Sociais. Situação de entrevista e estratégia do entrevistador. In: L. Albarello et. al. Práticas e Métodos de investigação em Ciências Sociais. Lisboa: Gradiva, pp. 84-116.

Saliba, M. G. (2007, fevereiro-março). A Nova Lei de Tóxicos: Usuários e Dependentes - Descriminali- 
zação, Transação Penal e Retroatividade Benéfi-

ca. Revista Magister de Direito Penal. Ano III, n. 16, pp. 10-25.

Trad, S. (2009) Controle do uso de drogas e prevenção no Brasil: revisitando sua trajetória para entender os desafios atuais. In: A. Nery Filho., et al. orgs. Toxicomanias: incidências clínicas e socioantropológicas. Salvador: EDUFBA; Salvador: CETAD, pp. 97-112.

Data de submissão/Submission date: 30.09.2016.

Data de aceitação para publicação/Acceptance date: 10.10.2017. 